Discussion Paper No. 03-06

\title{
Dynamic Optimal Capital Structure and Technological Change
}

Hans Lööf

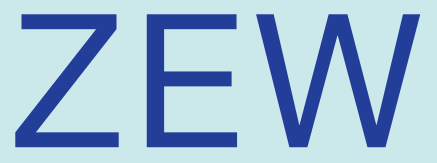

Zentrum für Europäische Wirtschaftsforschung GmbH

Centre for European

Economic Research 
Discussion Paper No. 03-06

\title{
Dynamic Optimal Capital Structure and Technological Change
}

\author{
Hans Lööf
}

Download this ZEW Discussion Paper from our ftp server:

\section{ftp://ftp.zew.de/pub/zew-docs/dp/dp0306.pdf}

Die Discussion Papers dienen einer möglichst schnellen Verbreitung von neueren Forschungsarbeiten des ZEW. Die Beiträge liegen in alleiniger Verantwortung der Autoren und stellen nicht notwendigerweise die Meinung des ZEW dar.

Discussion Papers are intended to make results of ZEW research promptly available to other economists in order to encourage discussion and suggestions for revisions. The authors are solely responsible for the contents which do not necessarily represent the opinion of the ZEW. 


\section{Non Technical summary}

This paper focuses on the determinants to optimal capital structure among different financial systems. Recent theoretical research on endogenous technological change stresses the it is entrepreneurial selection and the financing of tangible and intangible investment that lead to innovation. This research points out that policies that can improve the efficiency and costliness of financial markets, as well as extend their size exert a first-order influence on economic growth.

There are two archetypes of financial systems. Today the U.S and the U.K. are the best empirical examples of arm's-length systems (equity or market dominated systems), while Scandinavian countries, and most continental European countries are typically the relation-based systems (debt or bank dominated system). Comparing Sweden, U.K and U.S shows that the two Anglo-Saxon countries have 50-100 percent more equity financing than Sweden depending on measure used, while the ratio of debt to sales is highest in Sweden.

The empirical results in this study are based on a panel data set of corporations listed at the Stockholm Stock Exchange for period 1991 to 1998. Regression results based on Swedish listed company data are compared with those from two previous studies (for U.S firms and U.K firms) and for small non-listed Swedish firms respectively. All these studies used the same econometric framework and similar data sets.

The empirical approach is a dynamic specification allowing for adjustment of the capital structure over time. An important finding in the paper is that unlike in the U.S. case, the financial market in neither Sweden (bank dominated) nor U.K. (equity dominated) does favor a dynamic development of the economy driven by technological change. 


\title{
Dynamic Optimal Capital Structure and Technological Change
}

\author{
HANS LÖÖF*1, \\ February 2003
}

\begin{abstract}
This paper incorporates the cost of adjustment between observed and optimal leverage in explaining the variation in firm's equity or bank-debt financing investments. Using a dynamic adjustment approach identifies the determinants to capital structure between different financial systems. In relation to firm sales U.K and U.S firms have 50-100 percent more equity financing than Swedish firms depending on which measure used, while the ratio of debt to sales is highest in Sweden. The major findings are that observed leverage often deviates from the target leverage in both equity and debt dominated systems. There are large and also unexpected crosscountry differences in determinants to optimal capital structure. Swedish and U.K. firms deviate more from the optimal level than U.S firms. A faster speed towards the target is observed in the equity based systems.
\end{abstract}

Keywords: Capital structure, dynamic adjustment, panel data, optimal leverage, financial markets, cross-country comparison, technological change, innovation.

JEL Classification Numbers: C23, C51, G32. O16, O31

${ }^{*}$ Correspondence to Hans Lööf, KTH/Swedish Institute for Studies in Education and Research, SE-11428 Stockholm, E-mail: hansl@sister.nu. Phone +46-8-54525260, Fax +46-8-205270.

The author gratefully acknowledge financial support from Vinnova, Swedish Agency for Innovation Systems. The author thank participants at the North American Productivity Workshop, Union College Schenectady, New York, June 2002, participants of seminar held at Research Institute of Industrial Economics, Stockholm, Mars 2002, Gunnar Eliasson, Almas Heshmati, Stefan H Lutz, Pierre Mohnen and two anonymous referees for very helpful comments and suggestions on an earlier version of this paper.

${ }^{1}$ Hans Lööf, visiting research fellow at the Center for European Economic Research (ZEW) $2002 / 2003$ 


\section{INTRODUCTION}

Do particular financial institutions or their inefficiency have an impact on investments contributing to technological change, profitability and growth? While Miller and Modigliani (1958) derived conditions under which capital structure is irrelevant, an extensive body of subsequent theoretical contribution has convincingly shown how a firm can change its value and growth rate and improve future prospects by varying the optimal ratio between debt and equity.

Empirical research on how market failure can drive a wedge between various sources of financing investment in $\mathrm{R} \& \mathrm{D}$, structure, equipment and other investments (i.e., why all available information is not reflected in the prices of various securities) have mostly been explored within rather than between financial systems. Yet the rarely existing cross-country comparisons often take the industry level perspective. Moreover, the common approach in empirical capital structure research has been to study the association between the observed leverage and various explanatory variables. But using the observed level does not take into account the fact that firms typically are not the optimal level.

This paper focuses on the determinants to optimal capital structure between different financial systems. Recent theoretical research on endogenous technological change stresses the entrepreneurial selection and the financing of tangible and intangible investment that lead to innovation. Se King and Levine (1993), Aghion and Howitt (1998), Hall and Van Reenen (2000), Hall (2002). This research points out that policies that can improve the efficiency and costliness of financial markets, as well as extend their size exert a first-order influence on economic growth.

There are two archetypes of financial systems. Today the U.S and the U.K. are the best empirical examples of arm's-length systems (equity or market dominated systems). Sweden, other Scandinavian countries, and most continental European countries are typically the relation-based systems (debt or bank dominated system). In arm's-length systems stock markets, bond financing and retained earnings are the dominating forms of financing. Bank-loans serve mainly short term purposes. The relation based systems are characterized by long-term bank loans as the major source of investment financing. The relationship between particular banks and particular firms is mostly long term, and in such relationship the bank's risks are reduced 
because of it's supposed knowledge of the firm's prospects. Comparing Sweden, U.K and U.S shows that the two Anglo-Saxon countries have 50-100 percent more equity financing than Sweden depending on measure, while the ratio of debt to sales is highest in Sweden.

The empirical results are based on a panel data set of corporations listed at the Stockholm Stock Exchange 1991-1998. The conventional factors determining capital structure as reported in recent literature have been incorporated in the model, and the regression results are compared with those from two previous ( for U.S firms and U.K firms, and for small non-listed Swedish firms respectively) studies using the same econometric framework and similar data.

The empirical approach is a dynamic specification allowing for adjustment of the capital structure over time. This is in contrast to the common approach in empirical capital structure research. It is therefore possible to identify the determinants of optimal rather than observed capital structure. If firms have capital structures that are not at their target, and if they adjust their capital structure very slowly, it is an indication that any efforts to reach the optimal level are associated with both benefits and costs.

The major findings are following. First, observed leverage if often different from the target leverage in both equity and debt dominated systems. Second, there are large cross-country differences in determinants to optimal capital structure. Third, Swedish and British firms deviate more from the optimal level than U.S firms do. Fourth, a faster speed towards the target is observed in the equity based systems. Fifth, large similarities are found between large listed firms and small listed firms within Sweden when the market value leverage for listed firms is compared with the book the book value for non listed firms. A sensitivity test shows that the explanatory power increases dramatically when the cost of adjustment is incorporated in the model.

The organization of the paper is as follows. Section 2 presents theoretical background and important evidence on the presence of market imperfections. Section 3 presents the empirical model of capital structure. Sections 4 describe the data and variables used. Section 5 presents the estimation results. Section 6 concludes the main findings. 


\section{THEORETICAL AND EMPIRICAL BACKGROUNDS}

\subsection{Financial systems and economic performance}

One branch of literature dealing with determination of the relative amounts of debt and equity focuses on the link between the financial sector, industrial structure and growth. The common sense in this research is that the efficiency of a financial system is determined by its ability to mobilize savings, reduce risk of loss through moral hazard and adverse selection, distribute and reallocate resources to their most productive users without high or transactions costs, boost innovation, and ultimately stimulate industrial dynamics and growth. See Rajan and Zingales (1998), henceforth $\mathrm{RZ}$, for a discussion.

Of particular importance for the efficiency of a financial system is its capacity to channel resources to young firms and to knowledge intensive firms. Firms raise funds for new investments both internally from retained earnings and externally from the financial system through security issues. The corporate finance literature shows the presence of life cycle in the pattern of financing firms. Initially the demand for external funding is substantial, and decreases successively with the age of a firm. For a mature firm in a steady-state equilibrium the need for net external funds is limited. ${ }^{2}$ RZ (2001) suggest that if the young firms are innovators, contributing to Schumpeterian waves of creative destruction, the development of the financial system is crucial for aggregate economic growth.

Focusing particularly on entrepreneurial firms, a growing empirical literature provides evidence on financial constraints for small firms. Analyzing 724 SMEs from all major sectors of the Finnish economy, Hyytinen and Toivanen find evidence that capital market imperfections hold back innovation and growth for small and middle-sized firms. This finding is in line with results for other countries reported by Brown 1997, Bond, Harhoff, Van Reenen 1999, Bougheas, George and Strobl 2001.

The most valuable assets of knowledge intensive firms are related to $R \& D$ and human capital. RZ (2001) suggest that such intangible investments are easier to finance on the stock market since collateral is essential to obtain external financing by issuing debt to the banking sector. From a Schumpeterian point of view this means

\footnotetext{
2 Among established firms the need of external net funds is associated to technological shocks raising the investment opportunities beyond retained earning can support.
} 
that competitive advantage of an economy is closely associated with its supply of equity financing. Carlin and Mayer (1998) give support for this hypothesis when studying 27 industries in 20 OECD countries over the period 1970-1995. They find positive correlation between equity financing, R\&D-intensity, growth, and probably the very important factors of accounting standard. ${ }^{3}$

It can be assumed that the access to external financing for young firms and $R \& D$ investments for small and large firms is not independent from the size of the financial sector. In their cross-country study King and Levine (1993) find that the financial sector size is positively correlated with macroeconomic growth. But measuring the size of a financial market, however, is a bit tricky, as reported by La Porta et al (1997). In order to account for this problem they present eight different measures for 49 different countries, including Sweden and the two Anglo-Saxon countries that will be explored in this paper.

Table 1 shows that the U.K and the U.S have much bigger capital markets measured as the sum of debt and equity than Sweden. Three indicator measures are used for the equity capital as shares of total economy, while one indicator is expressed as the ratio of bank debt in the bank sector and outstanding nonfinancial bonds to GDP. Individually and together these four measures indicate an extensive difference between Sweden and the two Anglo-Saxon countries. They have a larger stock market in relation to GDP, three times more listed firms per population in million, 50-100 percent more initial public offering given to the population and 60100 percent higher ratio of bank debt of the private sector to GDP. The lower part of the table displays external funding at the firm level. In relation to firm sales the U.K and the U.S have 50-100 percent more equity financing than Sweden depending on measures used, while the ratio of debt to sales is higher in Sweden than in the both Anglo-Saxon countries. Another information read from the table is that the Swedish capital market has about the same size as the capital markets in several other European countries.

\footnotetext{
${ }^{3}$ Reporting similar findings as Carlin and Mayer, Beck (2001) uses industry-level data on firms' dependence on external finance for 36 industries and 56 countries and concludes that countries with better developed financial systems have higher export shares and trade balances in industries that uses more external finance. But the identified key area for improving the financial system is mainly juridical and includes strengthening creditor rights and contract enforcement through judiciary and juridical reforms.
} 


\section{2 Determinants to the optimal capital structure}

This subsection briefly reviews the literature on determinants to optimal capital structure, or debt equity choice. Taxes are the main reason for capital structure optimization. The advantage of corporate taxes in this respect is that interest payments are deductible as an expense. The consequence is that, ceteris paribus, the total income to both debt holders and stockholders is larger for a leveraged firm. Total income increases by interest payment times the tax rate. The optimal strategy for the value-maximizing firm would therefore be to acquire a maximum of leverage. The greater the amount of debt is, the greater the tax shield and the greater the value of the firm. But such a strategy is not consistent with empirical evidence. One main reason is related to the uncertainty of tax shields. The possibility of using tax shields effectively varies over the business cycle and among firms, depending on net income or profitability.

Another reason for tax shelter redundancy identified by Van Horn (1992) is that firms use alternative ways other than interest on debt to shelter income, for example leasing, investment in intangible assets and the use of options and future contracts. Other non-debt factors that reduce the incentives to issue debt to take advantage of interest shields are depreciation and amortization.

Bankruptcy costs are an intensively discussed important market imperfection affecting capital structure. With perfect capital markets, no bankruptcy costs are present since the firm's assets can be sold at its economic value and no transaction costs are involved. If capital markets are less than perfect, the security holders receive less than they would in the event of bankruptcy. Van Horne (1992) reports that the possibility of bankruptcy usually is not a linear function of the debt-to-equity ratio. It increases at a growing rate beyond some threshold.

Information asymmetry between insiders and outsiders can effect the firm's optimal capital structure. In financing new investment projects Myers and Majluf (1984), argue that well-informed management insiders will issue equity if they believe the existing stock is overvalued and debt if it believes the stock is undervalued. Razin, Sadka and Yuen (2001), however, draw the opposite conclusion and suggest that debt is preferred to equity since the choice of equity finance signals that the firm's shares are overvalued.

Titman (1984) argues that the more unique a firm's assets, the thinner the market for those assets and the lower the expected value recoverable by the lender in the 
event of bankruptcy. The idea is that a firm that develops and produces unique and specialized products also develops specialized or customized skills and competence capital that are not easily transferable. Consistent with this idea, Titman (1984) finds that firms in unique lines of business tend to be less leveraged.

Among market imperfections reported in the literature, that prevent the equilibrium of security prices from being reached, there are transaction costs which restrict the arbitrage process, and institutional restrictions on lender and stock investor behavior, and moral hazard problems due to principal agent-conflict between the separated ownership and management, which can result in investment strategies that are not value maximizing.

In addition to discussion on the over- or under valuation of stock prices, which can be applied on both profitability and growth opportunities, there are some more conflicting results that should be noted here. Larger firms are mostly diversified and fail less often. Size may therefore be an inverse proxy for the probability of bankruptcy and should have a positive impact on debt. On the other hand, size may also be a proxy for the amount of information that is available to the people outside the firm. This is expected to increase the preference of firms for equity relative to debt.

Jensen (1986) discusses the effects of profitability on leverage and predicts a positive correlation if the market for corporate control is effective, and negative otherwise. The negative relationship is explained by management's preference for internal financing while efficient corporate control forces the firm to pay out cash by leveraging up.

Does a conclusion of the theoretical literature and empirical evidence produce any robust evidence on determinants to optimal capital structure, which can serve as a guide in our subsequent analysis? In their extensive survey Harris and Raviv (1991) report that literature generally agrees that leverage is supposed to increase with fix assets, non debt tax shields, growth opportunities, and firms size, while leverage is supposed to decrease with volatility, research and development expenditures, bankruptcy probability, profitability, uniqueness of the product and advertising expenditures.

Investigating four determinants of capital structure choice by analyzing the financial decisions of public firms in all G-7 countries (the U.S., Japan, Germany, France, Italy, the U.K., and Canada), RZ (1994) differentiate between leverage 
expressed in book value and in market value. They showed that both measures of leverage increase with tangibility (fixed assets divided by total assets) and sales, and decrease with profitability and (in conflict with Raviv and Harris) the market-to-book ratio as a proxy for growth opportunities. In a cross-sectional analysis of a sample of 176 large firms, Asgharian (1997) shows that growth, size, collateral value of the assets and managers' shareholding positively affect firm leverage while profitability affects leverage negatively.

\section{EMPIRICAL FRAMEWORK}

\subsection{Dynamic models}

This study builds on dynamic modeling approach following a minor but growing trend in the literature. Jalivand and Harris (1984) were among the first to recognize the importance of a dynamic approach in finance theory in their study of the capital structure of firms. They characterized a firm's financial behavior as a partial adjustment to long-run financial targets. Fischer, Heinkel and Zechner (1989) used adjustment dynamics when they studied the difference between the maximum and minimum debt ratios of firms over a sample period of more than 8 years and tried to identify the factors that determined the range of capital structures. Rajbhandary (1997) estimated a dynamic adjustment model exploring Indian firm data.

Banerjee, Heshmati and Wihlborg (2000) represent one of the first attempts to apply a dynamic adjustment model and panel data methodology in capital structure analysis. The main finding is that firms typically have capital structures that are not at the target, and that they adjust very slowly towards the target. Their study highlights the issue of adjustment costs, which has been overlooked in previous literature. The $\mathrm{KHH}$-model used in this paper is an extension and development of the Benjare at al model.

The specification of the dynamic model here follows those outlined in Kumbhakar, Heshmati and Hjalmarsson (2002), in the following labeled as the KHHmodel, and Heshmati (2002). The principal idea in the model is that there is a tradeoff between the costs and the benefits of leverage, which implies an interior optimal debt level for a firm. 


\subsection{The optimal leverage ratio}

Assume that the optimal leverage ratio for a firm is a function of sets of variables as in the following equation:

$$
L_{i t}^{*}=F\left(Y_{i t}, X_{i}, X_{t}\right)
$$

where $L_{i t}^{*}$ is the optimal leverage ratio for firm $i$, at time $t, Y_{i t}$ is a vector of firm- and time-variant determinants of the optimal leverage, $X_{i}$ and $X_{t}$ are unobservable firmspecific and time-specific effects represented by firm and time dummy variables. The distinguishing feature of the $\mathrm{KHH}$ model is that it allows the optimal leverage to vary across firms and over time. The dynamic of this model means that the optimal debt ratio may move over time for an individual firm.

\subsection{The adjustment process towards optimal leverage}

Under ideal conditions one would expect that the observed leverage of firm $i$ at time $t$ is equal to the optimal leverage, i.e. $L_{i t}=L_{i t}^{*}$. In the dynamic model this would imply that the change in actual leverage from the previous period to the current period is equal to the change required for the firm to attain optimal leverage at time $t$. If adjustments to the rate of change required for the firm to reach optimal leverage at time $t$ are costly, as reflected in $L_{i t}$, then firms may not find it optimal to adjust fully, but only partially. This is represented as

$$
L_{i t}-L_{i t-1}=\delta_{i t}\left(L_{i t}^{*}-L_{i t-1}\right)
$$

which can be rewritten as

$$
L_{i t}=\left(1-\delta_{i t}\right) L_{i t-1}+\delta_{i t} L_{i t}^{*}+e_{i t}
$$

where $\delta_{i t}$ is the adjustment parameter representing the magnitude of desired adjustment between two subsequent periods, and $e_{i t}$ is statistical noise assumed to have mean zero and constant variance. 
If $\delta_{i t}=1$, the optimal adjustment is achieved within one period and the firm at time $t$ is at its target leverage. The effects of adjustment costs are represented by the restriction that $\left|\delta_{i t}\right|<1$, which is a condition that $L_{i t} \rightarrow L_{i t}^{*}$ as $t$ goes towards infinity. Finally, if $\delta_{i t}>1$, the firm overadjusts by making more adjustments than necessary. Overadjustment is a reflection of unanticipated changes in economic conditions.

\subsection{The speed of adjustment}

The speed of adjustment $\delta_{i t}$ may itself be a function of some underlying variables affecting adjustment costs:

$$
\delta_{i t}=G\left(Z_{i t}, M_{i}, M_{t}\right)
$$

where $Z_{i t}$ is a vector of variables determining the speed of adjustment, and $M_{i}$ and $M_{t}$ are unobserved firm-specific and time-specific effects. As with the optimal leverage, which may shift from period to period, the speed of adjustment is also allowed to vary across firms and over time.

An important feature of the $\mathrm{KHH}$ adjustment model is that the current and past levels of optimal leverage contain information that can be used to predict the future behavior of leverage, and that it does not take into account the target leverage beyond time $t$.

\subsection{The general functional relationships}

Finally the assumptions of the general functional relationships for the optimal leverage ratio, $L_{i t}^{*}$, and the adjustment parameter, $\delta_{i t}$, in the $\mathrm{KHH}$ model is given by

$$
\begin{aligned}
& L_{i t}^{*}=\alpha_{0}+\sum_{j} \alpha_{j} Y_{j i t}+\sum_{s} \alpha_{s} X_{s}+\sum_{t} \alpha_{t} X_{t} \\
& \delta_{i t}=\beta_{0}+\sum_{k} \beta_{k} Z_{k i t}+\sum_{s} \beta_{s} M_{s}+\sum_{t} \beta_{t} X_{t}
\end{aligned}
$$

where the firm-specific and time-specific variables $X_{i}, X_{t}, M_{i}$ and $M_{t}$, are replaced by industrial sector and time dummy variables. The $\alpha$ coefficients are short-run elasticities. The long-run elasticities are calculated as $\left(\alpha_{j} \delta\left(Y_{j} / L\right)\right.$. The specification 
of the model uses the determinant factors measured for the same period that $L_{i t}^{*}$ and $\delta_{i t}$ are determined.

\subsection{The estimation procedure}

The overall estimation procedure is starting by estimating the probability of the survival of firms. Using a probit model written as

$$
z_{i t}^{*}=\gamma^{\prime} w_{i t}+\eta_{i t}
$$

The parameter estimates are used for calculating the inverse Mill's ratio, introduced to correct for selection $\operatorname{bias}^{4}, M \hat{R}_{i t}=\phi\left(\hat{\gamma}^{\prime} w_{i t} / \hat{\sigma}_{\eta}\right)$. Mill's ratio, is then introduced as an extra explanatory variable in the optimal leverage equation (6), which is based on surviving firms, where $L_{i t}$ in equation (6) is observed only when the latent variable $z_{i t}>0$ :

$$
L_{i t} \mid z_{i t}>0=\left(1-\delta_{i t}\right) L_{i t-1}+\delta_{i t} L_{i t}^{*}+e_{i t}
$$

Equation (6) in the general functional relationship can then be respecified as:

$$
L_{i t}^{*}=\alpha_{0}+\sum_{j} \alpha_{j} Y_{j i t}+\sum_{s} \alpha_{s} X_{s}+\sum_{t} \alpha_{t} X_{t}+\alpha_{M R} M \hat{R}_{i t}+e_{i t}
$$

Where $\alpha_{M R}$ indicates the presence of a selection bias, while its sign and size indicate the direction and magnitude of the bias. Selection bias arises as a result of the exit, entry and non-response of firms. Since the model is non-linear in its parameters, the KHH model uses a nonlinear regression procedure. Explanatory variables include the vector of determinants of optimal capital structure Y (non-debt tax shields, income variability, expected growth, tangibility, size, profitability and uniqueness), and the vector of determinants of the speed of adjustment $Z$ (absolute distance from optimal

\footnotetext{
4 The restriction imposed regarding the frequency of firms to be observed reduced the total sample of 1,179 observations to 813 . Given the dynamic nature of the model, a firm must have been observed for at least three consecutive years. If firms with some sets of characteristics are more likely to be observed for three years or more, then the final sample is not randomly selected from the total sample and the estimates of the optimal capital structure may suffer from selection bias.
} 
debt ratio, expected growth, size and profitability) and vectors of unobservable $\mathrm{X}$ and $\mathrm{M}$ (time and industry) effects. ${ }^{5}$

\section{DATA, VARIABLES AND SOME PREILIMINAY FINDINGS}

The observations used in the study relates to firms listed on the Stockholm Stock Exchange during the period 1991-1998. The total number of annual observations varies between 117 and 221. Having specified the functional form in the previous section, we will now discuss measures of leverage and variables that determine the optimal capital structure and the speed of adjustment.

\subsection{Market and book values of leverage}

We will use two different definitions of leverage. In the first case the market value of equity and in the second case the book value of equity is used. The market value measure is essentially future-oriented, reflecting expected future cash flows from the tangible and intangible assets of the firm. The book value measure, on the other hand, largely reflects the performance history of the firm.

Given that the objective of the firm is to maximize its value, it is not obvious whether the real value is best captured by a historical perspective or by a future perspective. Since the information signaled in book value and market value is informative in different respects, many previous studies have used both simultaneously. However, our emphasize is on market value leveraged. This is motivated by the overall research issue on the impact of different financial system on the firms' growth opportunities.

\subsection{Determinants of optimal leverage}

Our set of determinants to optimal leverage is derived from the discussion in Section 2.2, and they are mainly those that have commonly been documented in the literature as affecting a firm's leverage. They are (1) Non-debt tax shields (the ratio of depreciation to total assets), (2) Income variability (the variance of sales), (3)

${ }^{5}$ For the purpose of comparing results of the dynamic model with those based on static models, we will also estimate the simple static model:

$$
L_{i t}=\alpha_{0}+\sum_{j} \alpha_{j} Y_{j i t}+\sum_{s} \alpha_{s} D_{s}+\sum_{t} \alpha_{t} D_{t}+\alpha_{M R} M \hat{R}_{i t}+e_{i t}
$$


Tangibility (fixed assets divided by total assets), (4) Profitability (net profit), (5) Uniqueness (the average wage level), (6) Expected growth (the percentage change in total assets from the previous to the current year), and (7) Firm size (employment). In order to control for any time-specific and industry-specific effects that may not be captured by the variables above, we also include time dummies and dummies for different industry classifications of the firm.

\subsection{Determinants of the speed of adjustment}

The speed of adjustment towards the optimal capital structure is determined by the costs of shifting from one capital structure to another. Three explanatory variables are included in the regression that captures the adjustment speed, two of which are identical to variables that determine the optimal level of debt. The variables are distance, growth opportunity, firm size and unobservable firm-specific and timespecific effects. We will explain them briefly in the following:

Distance between observed and optimal leverage: If fixed costs constitute a major portion of the total costs of changing capital structure, firms with sub-optimal leverage will alter their capital structure only if they are sufficiently far from the optimal capital structure. The likelihood of adjustment is a positive function of the difference between optimal and observed leverage. The relationship between the speed of adjustment and distance from the optimal capital structure is supposed to be negative if leverage is adjusted slowly and internally via the firms' dividend policy. The correlation is positive if the firms adjust their leverage in external capital markets when deviations are sufficiently large.

Growth opportunity: Growth opportunity is the second of our determinants of optimal capital structure. The paper assume that the larger growth opportunities are, the faster adjustment towards optimal capital structure is since a growing firm may find it easier to change its capital structure by choosing among several alternative sources of financing.

Firm size: Firm size is expected to be positively correlated with the speed of adjustment. It can be assumed that larger firms may find it easier than small firms to change their capital structure by issuing debt or equity because more information is available about larger firms. 
Unobserved firm-specific and time-specific effects: In addition to the distance, growth opportunity and size variables, a set of time-dummy variables is included to capture unobservable time-varying effects that are common to all firms. They are supposed to capture macro factors like the general economic condition, interest rates, money supply and the labor market situation.

\subsection{Some preliminary findings}

The statistics for Swedish firms reported in Table 2 show that the ratio of the market value of equity increased dramatically between 1991 and 1998. While the market value in 1998 was 90 percent higher than in 1991, the 1998 book value of equity was only 12 percent higher than its 1991 level. These figures reflect in part the shift of the Swedish economy from its deepest economic recession since the 1930s to an economic boom, which peaked in the year 2000, as well as the strong increase in the international valuation of technological firms in general during the 1990s. In particular Telecom (Ericsson) have a strong impact on the performance of the Stockholm Stock Exchange.

Table 3 supplements the information on heavily debt financed Swedish firms provided in Table 1. The average level of market value leverage for the listed firms was 53\% between 1991 and $1998 .^{6}$ The Banerjee, Heshmati and Wihlborg balanced panel data we utilize on our analysis show that the average market value leverage is $40 \%$ in the sample of the 483 listed firm in the U.S, observed between 1989 and 1996, and only $14 \%$ in the sample of the 122 U.K. firms observed between 1990 and 1996. The book value leverage is $26 \%$ for the U.S. firms and $14 \%$ for the U.K. firms.

The number of annual observations in the unbalanced Swedish sample increased gradually from 117 in 1991 to 221 in 1998. About 70 percent of the observations represent firms with 251 or more employees. Eight different industry classifications are used in the study, with knowledge-intensive services being the largest group, including business services, bank, insurance, $R \& D$ firms and ICT firms.

\section{EMPIRICAL RESULTS}

This Section presents the cross-country and inter-country comparisons of the determinants to capital structure. The results are reported in Table 4-6. First, the

\footnotetext{
${ }^{6}$ Note that we define leverage as debt/debt + equity
} 
Swedish parameter estimates ${ }^{7}$ are compared with results for U.K. and U.S. obtained from Banerjee, Heshmati and Wihlborg (2000) using market value leverage, the same econometric framework and similar data. Second, the parameter estimates of book value of leverage for firms listed at the stock exchange in Sweden are compared to book value estimates for Swedish non-listed small firms. The results from non-listed firms are taken from Heshmati (2002). To broaden the discussion, book-value leverage estimates for the two Anglo-Saxon countries are also reported.

\section{1. Cross-country differences in the determinants of capital structures}

A priori the differences in the determinants of optimal capital structures in Sweden, the U.K. and the U.S. should be expected to have gradually shrunk in the 1990s. The reason for this is deregulation of the financial industry - in the United States in the 1980s and in most other industrial countries, including Sweden in the 1990 s, lower international inflation rates and nominal interest rates, and the increased globalization of financial markets.

\subsection{Non-debt tax shields}

The main incentive for borrowing is to take advantage of interest tax shields. This advantage is reduced with the presence of non-debt tax shields such as depreciation and amortization.

Using the ratio of depreciation to total assets in order to measure the existence of non-debt tax shields, a negative relationship between this variable and the optimal leverage should be expected in highly- leveraged Sweden, and a weak correlation or no correlation at all in the low-leveraged U.K. and U.S. This is also what the results

\footnotetext{
${ }^{7}$ Initially two models were tested: a standard static model, and an unrestricted flexible adjustment dynamic model. For both, time dummy and time-trend specifications are estimated, and they are estimated using both market value and book value leverage. The static model assumes instantaneous adjustment and the adjustment coefficient $\delta$ is 1 . That is, there is no difference between the observed and the optimal leverage ratios. In the dynamic model the assumptions for adjustment imply that different firms have different speeds of adjustment towards their firm-specific optimal capital structure. The root mean squares error (RMSE) and the coefficient of determination $\left(R^{2}\right)$ show a large difference between the static model and the two dynamic models. The superiority of the dynamic models is illustrated by their lower RMSE, 0.07-0.09 compared to 0.14-0.18 for the static model, and higher $\mathrm{R}^{2}, 0.81$ 0.87 versus $0.34-0.40$. A sensitivity test shows that the increase of explanatory power is mainly due to the introduction of a constant lag-dependent variable. To save space the results from the static model and the sensitivity test are not reported in this paper. Please consult the author to receive the estimates.
} 
presented in Table 4 show. The coefficient is highly significant and large, -3.79 , for Sweden while it is negative but insignificant for the U.K. and positive but insignificant for the U.S. Contrary to Sweden this indicates limited or non-incentive to increase the leverage because of corporate taxes.

\subsection{Income variability}

The variation in a firm's income is supposed to influence its optimal leverage negatively because the more variable a firm's operating income, the greater the risk that the firm will be unable to cover its interest payments and the higher the probability of bankruptcy is. Since operating income represents the income available for interest payment and is independent of the effect of leverage, we use variance of sales to measure income variability.

The coefficients are indeed negative in all three countries, although they are approximately zero and insignificant in Sweden and in the U.K. In the U.S. the size of the estimate is -0.34 but only significantly different from zero at the $10 \%$ level of significance. The surprisingly weak explanatory power of this variable might be due to the fact that the period of study partly coincided with a period of strong economic recovery in all three countries and a generally positive trend in revenues.

\subsection{Expected growth}

The literature on the impact of expected growth is conflicting and different proxies for this variable are perhaps one explanation to this result. Here the growth variable is defined as the percentage change in total assets from the previous to the current year.

The parameter estimates for Sweden are weakly positive (0.02) and highly significant. The economic interpretation is that firms with a higher growth potential did make use of this situation to pay down debt and reduce their leverage, however only to a smaller extent. The growth coefficient for the U.K. shows the negative sign and the order of magnitude is rather large, -0.60 , but insignificant.

The both European estimates can be compared with the U.S estimate, which shows a highly significant and large estimate (0.94). Perhaps this result can be explained by changes in financial regulation in the 1990s, encouraging the lowleveraged firms with positive growth perspectives to begin to borrow more from 
banks as a result of increased competition in this industry. Jayarante and Strahan (1996) give support for this interpretation. They found that deregulation leads to improvements in loan quality, which leads to better growth. An additional interpretation is that well-informed U.S. insiders believed that the existing stock was undervalued and consequently issued debt. Moreover, it may be an indicator of a strong signal value of intangible capital, which the American capital market seems to perceive better than European capital markets do.

\subsection{Profitability}

It was previously assumed that promising future prospects on profitability should be expected to correlate negatively with leverage. But recent works on asymmetric information and signaling effects have found that the result depends on assumptions on over- or undervaluation of the existing stocks.

The reported results show a negative, highly significant and large coefficient for Sweden (-2.66) and for the U.K. (-0.64), which can be interpreted in compliance with the undervaluation hypothesis. The firms utilized the positive development at the stock markets during the 1990 s to issue equity. The U.S. parameter estimate, on the contrary, has positive sign but the coefficient is not statistically different from zero.

\subsection{Uniqueness}

In line with the literature we expect negative relationship between uniqueness and leverage. Unfortunately, the definition of uniqueness differs between Sweden and the two other countries. While the variable for U.K. and U.S. firms is defined as the ratio of research and development to sales, the measure for Sweden is simply the wage level. This is assumed to be a proxy for the knowledge capital.

Uniqueness does not appear to be a significant factor determining leverage for listed firms in Sweden and the U.K. The parameter estimate is -0.05 for Swedish firms and 0.12 for U.K. firms, but it is not significantly different from zero in both cases. In contrast, the coefficient for the U.S. is statistically significant and surprisingly the sign is positive. The American security holders do not hesitate to invest in R\&D-intensive firms. The intangible nature of the uniqueness variable does not seem to worry credit providers in the U.S. that the firm will be unable to cover its interest payments. 


\subsection{Tangibility}

It is easier for the lender to establish the value of tangible rather than intangible assets because typically there is more asymmetric information about the value of intangibles. Moreover, in the event of bankruptcy, intangible assets such as goodwill and structural capital will rapidly disappear, thus reducing the net worth of a firm and further accelerating the possibility of bankruptcy. And as reported in Section 2, in economies with less developed financial markets collateral is more essential to obtain outside financing), compared with the most advanced financial systems. Thus, firms with a greater percentage of their total assets composed of tangible assets is supposed to have a higher capacity for raising debt, and we assume that this variable is more important in Sweden than in the U.K and the U.S.

This is also completely confirmed by the results. Expressing tangibility as fixed assets to total assets the parameter estimate is positively and statistically highly significant for Sweden, and the size is 0.35. The coefficient is positive but insignificant for the U.S. and negative and insignificant in the case of the U.K.

\subsection{Firm size}

A large firm is typically more diversified and could therefore be assumed to face a lower probability of bankruptcy. One would thus expect that the larger the firm size the higher the optimal debt capacity. The size measure used is employment.

The size coefficient is positive and highly significant in Sweden, positive and significant in the U.K., but negative and highly significant in the U.S. The results are consistent with the theoretical prediction when Sweden and the U.K. are considered. The unexpected sign for U.S. firms could possibly mean that small firms use venture capital (which is a mixture between arm's-lengths relation based external capital) to a larger extent than firms in Europe to finance their initial growth, but use bank financing for subsequent growth and then increase their leverage. However, the size of the parameter estimates is small for all three countries: Sweden (0.07), U.K (0.02) and U.S (-0.04).

\subsection{Unobserved time-specific effects and industry-specific effects}

The unobserved time-specific effects in the model are represented by timedummy variables. A presence of significant time effects can be interpreted as meaning that there are unobserved heterogeneous time-specific and time-invariant 
effects that are not captured by the seven observable explanatory variables. In addition to time-dummy variables, the three samples contain a set of industry-dummy variables to capture unobservable effects that are common to all firms. The regression results show that the unobserved time-specific and industry specific effects have strong explanatory power only for Sweden.

\subsection{Speed of adjustment and the difference between observed and optimal ratio}

\subsection{Speed of adjustment}

Panel B of Table 4 presents the speed of adjustment towards optimal capital structure. The determinants are (a) absolute distance towards the target, (b) growth rate, (c) firm size, and (d) unobserved time-specific effects.

Only the parameter estimate for unobservable time specific effects is significant when Sweden is considered. Interestingly they indicate that the speed of adjustment goes from positive and significant in the beginning of the 1990s to negative and significant at the end of the decade. ${ }^{8}$ The economic interpretation of these results is as follows: The speed of adjustment towards optimal leverage increased at the end of the deep recession, 1991-1993, and the average listed firm experienced an overshooting of its target in the strong boom period, while in the second half of the 1990s firms responded with a downward adjustment.

For both the U.K. and the U.S. coefficients for expected growth are negative and statistically significant. This means that firms with higher growth opportunities adjust more slowly towards the optimal capital structure, which is quite surprising. The result does not lend support to the commonly held view that growing firms find it easier to change their capital structure by altering the composition of the new capital they raise. The U.K. and U.S. coefficients for size are positive and significant, indicating that large firms are more concerned about capital structure than small firms. The parameter estimate for the distance variable is significant only for firms in the U.K. and the sign is negative. This indicates that it is less costly to adjust by relatively small amounts. A small adjustment can be achieved as part of a firm's normal operations, while larger adjustments require new issues of securities.

8 Since the time and industry dummies are not identically defined between the three countries, the parameter estimates are not reported in any of the tables. 
The coefficients for time-specific effects of the U.K. firms are negative and significantly different from zero throughout the period considered. The economic meaning is that the U.K. firms were in a downward adjustment process for the whole period. The U.S. time-dummy parameter estimates also indicate a weakly downward adjustment process.

\subsection{Observed and optimal leverage}

The cross-country comparison using market value leverage concludes with an analysis of the ratio of mean values of the optimal leverage $\left(L^{*}\right)$, and the observed leverage $(L)$, which will be expressed as the ratio $\left(L^{*} / L\right)$, and the adjustment speed $(\delta)$.

The annual rate of adjustment toward optimal capital structure for Swedish listed firms reported in Table 5 varied between $8 \%$ and 14\% between 1992 and 1998. The optimality ratio was improving during the 1990s and approached unity at the end of the period, $\left(\left(L^{*} / L\right) \rightarrow 1\right)$, although the process is not unequivocal.

The parameter estimates for the U.K. show that the optimality ratio for the mean firm is frequently different from the target. In general, the U.K. firms seem to be over-leveraged and the annual rate of adjustment varied between $11 \%$ and $65 \%$ between 1991 and 1996. The U.S. firms are close to optimal leverage for the entire period under consideration.

The overshooting of the optimal debt level by Swedish firms in 1992, and the structural overshot in the U.S. for the whole period except for 1993 deserve some more attention. The downturn in Swedish business cycle pre-1992-period resulted in low demand and creation of overcapacity in production. Given fixed capital and a rigid labor market combined with low profitability made the optimal leverage exceed the observed level. However, over time the optimality ratio declined as firm's profitability increased and more internal resources were used. The continuous overshooting in the US might reflect the increasing optimality and the need for expansion as a result of positive growth rates in the US economy throughout the 1990s.

\subsection{Non-listed firm versus listed firms}

The result section concludes by considering listed and mainly large firms and small non listed firms in Sweden. Comparing their book-value leverage table 6 
shows large dissimilarities. In fact the book-value measure for the non-listed firms seems to be more comparable with the market value measure for listed firms, reflecting that managers in the listed firms are most concerned over the market value leverage, while the listed firms have no alternative to book value leverage.

While non-debt tax shields, income variability, profitability uniqueness, and tangibility have more or less the same impact on capital structure, using different definitions on leverage for the both categories of firms, growth opportunities and size are conflicting variables. However, although the signs are the opposite and both estimate are highly significant, the order of magnitude of the coefficient for growth opportunity is approximately zero for both categories of firms. Firms expecting higher growth do not change their mix of debt and equity in the focused measure of leverage. The parameter estimate for size is only weakly significant and the order of magnitude nearly zero for the small firms. Probably this reflects that a large part of the firms are very small (1-10 employees) and that the variation is size is limited. Contrary to listed firms (and market value leverage) distance to optimal leverage has a positive impact on the speed of adjustment for non-listed firms, but not for listed firms. This indicates a positive association between the gap between optimal and observed leverage ratios and the speed at which the firm might fill the non-optimality gap.

The conclusion here is that although both categories of firms have different conditions on the capital market, collateral dominates as the signaling information for raising external funds (issuing debt) and the inverse measure for the importance of corporate taxes (non-debt tax shields) has a strong explanatory power for increasing the leverage. Further, both listed and non-listed firms did make use of profitability to increase the equity, through retired earnings and in the case of listed firms raising funds from the stock market.

\section{CONCLUDING REMARKS}

This paper examined whether firms in different financial systems share same determinants of the capital structure. We used a methodological approach recently developed to estimate a dynamic specification and allowing for adjustment of the capital structure over time.

Our analysis provides evidence that the size of the financial sector, the supply of equity capital and different systems of taxation result in different behavior concerning 
optimization of capital structure. Although the firms are frequently not on their target level, the deviation is smaller for the highly equity dependent U.S firms. They also adjust faster towards the optimal structure compared with the debt dependent Swedish firms. However, the also highly equity financed U.K. firms are further away from the target than Swedish firms, but facing lower costs to adjust towards the target.

For both categories of Swedish firms considered, listed and mainly large and non listed small firms, physical capital as a security and corporate taxes (due to deduct interest rates as an expense) were found to be the two main determinants to increased leverage. On the contrary, and quite surprisingly, the most important reason for increased leverage in the U.S was growth opportunities and uniqueness. This can partly be explained by the financial regulation in the 1990s, which encouraged the low leveraged firms with promising growth perspective to borrow more from competing banks. The well informed insiders knowledge about the (undervalued) value of the existing stock has probably played a role as well. Moreover, and very important, the positive sign for growth opportunities and uniqueness in the U.S. may also be an indicator of a strong signal value of intangible capital such as R\&D and knowledge.

One key objective of this paper was to investigate whether particular financial institutions or their efficiency have an impact on investments contributing to technological change, profitability and growth. The literature stresses the importance of future oriented investment in this respect. Based on our results a tentative answer is $y e s$ in the cases of Sweden and the U.S, and no in the case of U.K. The combination of a large size of the financial market and a broader variety through an extensive stock market, increased competition in the bank sector and a growing venture capital market creates favorable conditions for in intangible investments in the U.S. The financial market in neither Sweden (bank dominated) nor U.K. (equity dominated) does strongly favor a dynamic development of the economy driven by technological change and creative destruction. 


\section{REFERENCES}

Aghion, P. and P. Howitt. (1998), Endogenous Growth Theory, MIT Press, Cambridge MA.

Asgharian, H. (1997), Essays on Capital Structure, Lund Economic Studies Number 64, Lund University, Sweden.

Banerjee, S., A. Heshmati, and C. Wihlborg. (2000), The Dynamics of Capital Structure, SSE/EFI Working Paper Series in Economics and Finance. No 333.

Beck, T. (2001) Financial Dependence and International Trade. Working paper, Word Bank.

Bond, S., D. Harhoff, and J Van Reenen. (1999), Investment, R\&D and Financial Constraints in Britain and Germany. Institute of Fiscal Studies Working Paper no $99 / 5$.

Brown, W. (1997) R\&D Intensity and Finance: Are Innovative Firms Financially Constrained? London School of Economics Financial market Group.

Bougheras, S., H. Goerg, and Eric Strobl. (2001) Is R\&D Financially Constrained? Theory and Evidence from Irish Manufacturing. University of Nottingham.

Carlin, W and C Mayer (1999), Finance, Investment and Growth, mimeo, University of Oxford

Fischer, E. O., R. Heinkel and J. Zechner. (1989), Dynamic Capital Structure Choice: Theory and Tests, Journal of Finance 46 (1), 297-355.

Hall, B.H. (2002), How Effective are Financial Incentives for R\&D? A New Review of the Evidence, Research Policy 29, 449-469.

Hall, B. H. (2002), The Financing of Research and Development, NBER No 8773.

Harris, M. and A. Raviv. (1991), The Theory of Capital Structure, Journal of Finance 46(1), 297-355.

Heshmati, A. (2002), The Dynamics of Capital Structure: Evidence from Swedish Micro and Small Firms, Research in Banking and Finance 2, 199-241.

Hyytinen, A. and O. Toivanen. (2002), Do Financial Constraints Hold Back Innovation and Growth? Evidence of the Role of Public Policy. The Research Institute of the Finnish Economy. WP no 820.

Jalivand, A. and R. Harris.(1984), Corporate Behavior in Adjustment to Capital Structure and Dividend Targets: An Econometric Study, Journal of Finance 39(1), 127-145.

Jayaratne, J., P. E. Strahan. (1996), The Finance-Growth Nexus: Evidence from Bank Branch Deregulation, Quarterly Journal of Economics, vol 11 (3), 639-670. 
Jensen, M. (1986), Agency Costs of Free Cash Flow, Corporate Finance Takeovers, American Economic Review 76(2), 323-339.

King, R. G., and R Levine (1993), Finance and Growth: Schumpeter Might be Right. Quarterly Journal of Economics, 108 (3), 717-737.

Kumbhakar, S. C., A. Heshmati and L. Hjalmarsson (2002), How Fast Do Bank Adjust? A Dynamic Model of Labor-Use with Application to Swedish Banks, Journal of Productivity Analysis 18,1, 79-102.

La Porta, R. F. Lopez-De_Silanes, A Shleifer and R.W. Vishny (1997), Legal Determinants of External Finance. Journal of Finance 52(1), 1131-1150.

Modigliani, F. and M.H. Miller (1958), The Cost of Capital, Corporation Finance and the Theory of Investment, American Economic Review 48, 261-297.

Myers, S. C. and N. S. Majluf (1984), Corporate Financing and Investment Decisions When Firms Have Information That Investors Do Not Have. Journal of Financial Economics, 13, 187-222.

Rajan, R.G. and L. Zingales (1994), What Do We Know About Capital Structure? Some Evidence from International Data, NBER No 4875.

Rajan, R.G. and L. Zingales (1998), Financial Dependence and Growth. American Economic Review, 88(3). 261-97.

Rajan, R.G. and L. Zingales (2001), Financial Systems, Industrial Structure, and Growth. Oxford Review of Economic Policy 17: 467-482.

Rajbhandary, A. (1997), Capital Structure of Firms in Developing Countries: Results for India, Unpublished Manuscript.

Razin, A., E. Sadka and C. W. Yuen (2001), Why International Equity Inflows to Emerging Markets are Inefficient and Small Relative to International Debt Inflows. NBER Working Paper 8659.

Titman, S. (1984), The Effect of Capital Structure on a Firm's Liquidation Decisions, Journal of Financial Economics 13, 137-151.

Toy, N., A. Stoneholl, L. Remmers, R. Wright and T. Beckhusien (1974), A Comparative International Study of Growth Profitability and Risk as Determinants of Corporate Debt Ratios in the Manufacturing Sector, Journal of Financial and Quantitative Analysis, 9, 875-886.

Van Horne J. C. (1992), Financial Management and Policy, Ninth Edition, Prentice Hall, Englewood Cliffs, New Jersey. 
Table 1: The Size of financial markets

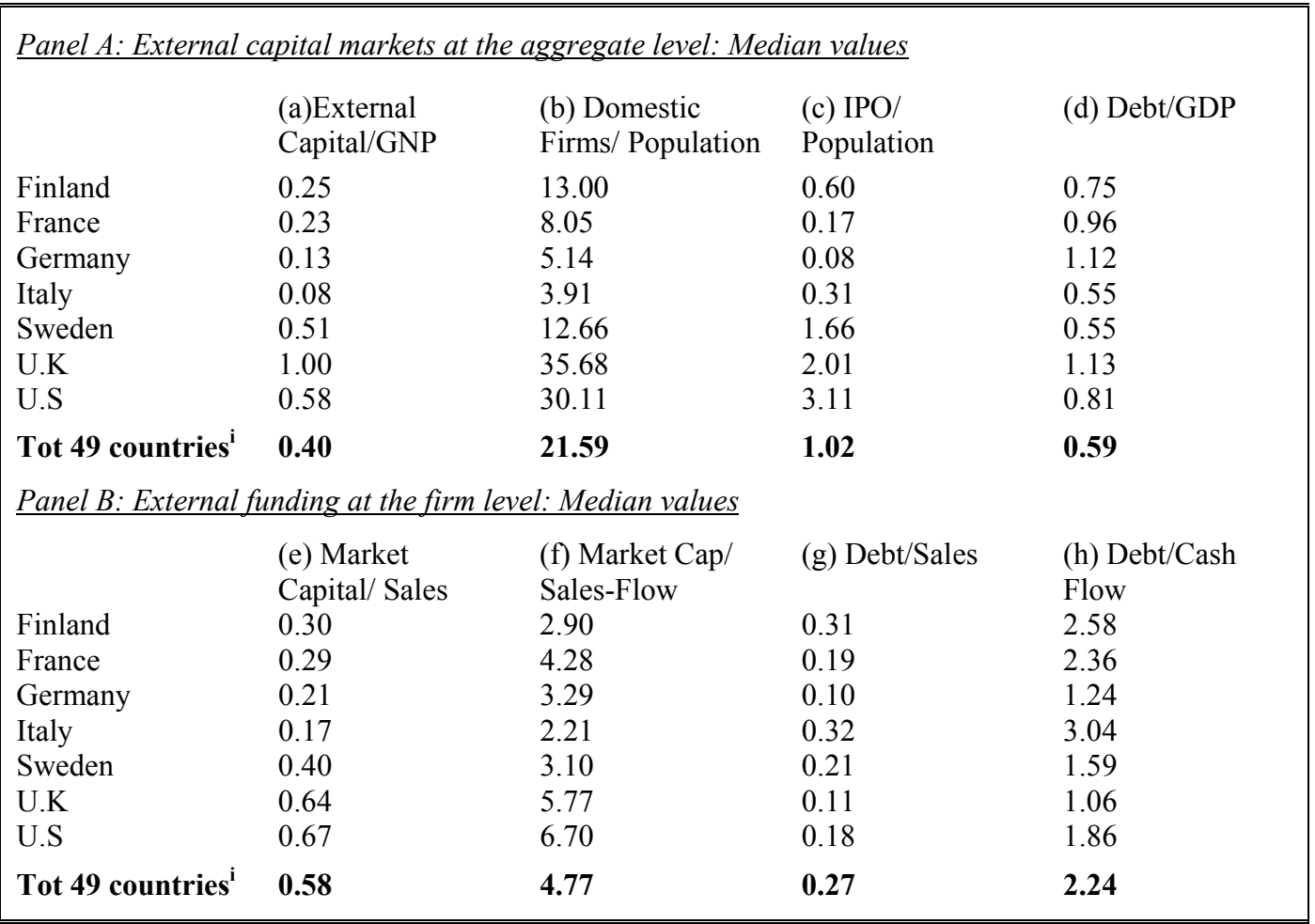

Notes: (a) The ratio of stock market capitalization held by minorities to gross national product for 1994.

(b) Ratio of the number of domestic listed firms in a given country to its population in million for the period 1995:7-1996:6.

(c)Initial public offerings of equity in a given country to its population.

(d) Ratio of the sum of bank debt of the private sector and outstanding nonfinancial bonds to GDP in 1994 or last available.

(e) The median ratio of stock market capitalization held by minorities to sales in 1994 for all nonfinancial firms.

(f) The median ratio of the stock market capitalization held by minorities to cash flow in 1994 for all nonfinacial firms.

(g) Median of the total-debt-to-sale in 1994 for all firms.

(h)Median of the total-debt-to-cash-flow ratio for all firms.

(i) Sample average

Source: La Porta et al (1997) 
Table 2: Market value and book value of equity 1991-1998.

Total Sample of Firms Listed on the Stockholm Stock Exchange 1991-1998 $(\mathrm{NT}=1,179)$

\begin{tabular}{|c|c|c|c|c|c|c|c|c|}
\hline & \multicolumn{2}{|c|}{$\begin{array}{l}\text { Market value } \\
\text { of equity }\end{array}$} & \multicolumn{2}{|c|}{$\begin{array}{l}\text { Book value } \\
\text { of equity }\end{array}$} & \multicolumn{2}{|c|}{ Total debt } & $\begin{array}{l}\text { Market value } \\
\text { leverage }\end{array}$ & $\begin{array}{l}\text { Book value } \\
\text { leverage }\end{array}$ \\
\hline$\underline{\text { Year }}$ & Mean & Index & Mean & Index & $\underline{\text { Debt }}$ & Index & Mean & Mean \\
\hline 1991 & 3601 & 100 & 2597 & 100 & 6098 & 100 & $63 \%$ & $70 \%$ \\
\hline 1992 & 3875 & 108 & 2690 & 104 & 6431 & 105 & $62 \%$ & $71 \%$ \\
\hline 1993 & 5554 & 154 & 2798 & 108 & 6222 & 102 & $53 \%$ & $69 \%$ \\
\hline 1994 & 5366 & 149 & 2837 & 109 & 5000 & 82 & $48 \%$ & $64 \%$ \\
\hline 1995 & 6095 & 169 & 3338 & 129 & 5205 & 85 & $46 \%$ & $61 \%$ \\
\hline 1996 & 9139 & 254 & 3997 & 154 & 5815 & 95 & $39 \%$ & $59 \%$ \\
\hline 1997 & 10230 & 284 & 4090 & 157 & 5891 & 97 & $37 \%$ & $59 \%$ \\
\hline 1998 & 6886 & 191 & 2905 & 112 & 4630 & 76 & $40 \%$ & $61 \%$ \\
\hline
\end{tabular}

Note: $\quad$ Market value of leverage $=(\mathrm{debt} /(\mathrm{debt}+$ market value of equity $))$. Book value leverage $=$ (debt/(debt + book value of equity)

Table 3: Summary statistics of the data

Unbalanced panel $(N T i=813)$

\begin{tabular}{|l|c|c|c|c|}
\hline \hline Variable & Mean & Std dev & Minimum & Maximum \\
\hline Book value \% & 0.602 & 0.179 & 0.010 & 1.000 \\
Market value \% & 0.525 & 0.235 & 0.010 & 0.988 \\
Non-debt tax shields \% & 0.039 & 0.026 & 0.000 & 0.303 \\
Income variability \% & 11.520 & 3.720 & 1.231 & 21.937 \\
Expected growth, \% & 3.512 & 25.288 & -100.000 & 88.927 \\
Profitability 1) & 0.025 & 0.098 & -1.328 & 0.268 \\
Uniqueness \% & 0.054 & 0.338 & 0.000 & 8.578 \\
Tangibility \% & 0.535 & 0.257 & 0.000 & 0.993 \\
Size sales 1) & 6.915 & 2.557 & 0.000 & 11.705 \\
Size employment & 7185 & 15950 & 1 & 121148 \\
Size employment & 7185 & 15950 & 1 & 121148 \\
\hline \hline
\end{tabular}

Note: (1) Million Swedish Crowns 
Table 4. Parameter estimates of the dynamic capital structure model. Determinants of optimal leverage defined as market value leverage and the adjustment speed towards the target

\begin{tabular}{|c|c|c|c|c|c|c|c|c|c|c|}
\hline \multirow[t]{2}{*}{ Variable } & \multirow[t]{2}{*}{$\begin{array}{c}\text { Expected } \\
\text { sign }\end{array}$} & \multicolumn{3}{|c|}{ Sweden } & \multicolumn{3}{|c|}{ U.K. } & \multicolumn{3}{|c|}{ U.S } \\
\hline & & Coeff & S.E & Sig. & Coeff & S.E & Sig. & Coeff & S.E & Sig. \\
\hline \multirow{2}{*}{\multicolumn{11}{|c|}{$\begin{array}{l}\text { Panel A: } \\
\text { Optimal leverage }\end{array}$}} \\
\hline & & & & & & & & & & \\
\hline NDTS & $(-)$ & -3.79 & 1.39 & $* * *$ & -0.25 & 0.52 & & 0.23 & 0.15 & \\
\hline VARI & $(-)$ & -0.01 & 0.01 & & -0.01 & 0.28 & & -0.35 & 0.21 & $*$ \\
\hline GROW & $( \pm)$ & 0.02 & 0.00 & $* * *$ & -0.60 & 0.44 & & 0.94 & 0.02 & $* * *$ \\
\hline PROF & $( \pm)$ & -2.66 & 0.48 & $* * *$ & -0.64 & 0.12 & $* * *$ & 0.13 & 0.08 & \\
\hline UNIQ & $(-)$ & -0.05 & 0.07 & & 0.12 & 0.57 & & 0.26 & 0.13 & $* *$ \\
\hline TANG & $(+)$ & 0.35 & 0.12 & $* * *$ & -0.06 & 0.09 & & 0.05 & 0.06 & \\
\hline SIZE & $(-)$ & 0.07 & 0.02 & $* * *$ & 0.02 & 0.01 & $* *$ & -0.04 & 0.00 & $* * *$ \\
\hline MILL'S & & -0.04 & 0.01 & $* * *$ & & & & - & & \\
\hline \multicolumn{11}{|l|}{ Dummies } \\
\hline Industry & & & Yes & & & Yes & & & Yes & \\
\hline Time & & & Yes & & & Yes & & & Yes & \\
\hline \multicolumn{11}{|c|}{ Panel B: } \\
\hline \multicolumn{11}{|c|}{ Adjustment speed } \\
\hline DIST & & 0.01 & 0.01 & & -8.68 & 2.54 & $* * *$ & 0.00 & 0.00 & \\
\hline GROWTH & & 0.00 & 0.00 & & -0.28 & 0.13 & $* *$ & -0.18 & 0.01 & $* * *$ \\
\hline SIZE & & 0.00 & 0.00 & & 0.04 & 0.02 & $*$ & 0.01 & 0.00 & $* *$ \\
\hline $\mathrm{R}^{2}$ adjusted & & 0.88 & & & 0.80 & & & 0.87 & & \\
\hline RMSE & & 0.09 & & & 0.06 & & & 0.06 & & \\
\hline
\end{tabular}

Notes: $\quad$ Sweden: Unbalanced panel 1991-1998, 117-221 observations per year. U. K.: Balanced panel 1990-1996, 122 observations. U. S.: Balanced panel 1989-1996, 438 observations. Expected signs in parentheses. The parameter estimate for the selection effect, Mill*s ratio, is negative and significant at the $1 \%$ level of significance for Sweden.

Panel A:

NDTS: non-debt tax shields, VARI: Income variability. GROW: Expected growth. PROF: Profitability. UNIQ: Uniqueness TANG: Tangibility. SIZE: Firm size.

Panel B:

DIST: Absolutely distance to optimal capital structure. Positive coefficient indicates that it is costly to adjust by relatively small amounts.

GROWTH: Expected growth. Positive coefficient indicates that firms with growth opportunity adjust faster towards the optimal capital structure.

SIZE: Positive sign indicates that large firms adjust faster toward the target.

Source: The results for U.K and for U.S is from Banjerjee, Heshmati Wihlborg (2000) 
Table 5. Optimality Ratio: Estimated optimal leverage ( $L_{i t}^{*}$ ) over observed leverage $\left(L_{u}\right)$, and annual rate adjustment speed $(\delta)$ towards optimal leverage.

Listed firms Sweden, the U.K. and the U.S.

\begin{tabular}{|c|c|c|c|c|c|c|}
\hline \multirow[t]{2}{*}{ Year } & \multicolumn{2}{|c|}{ Sweden } & \multicolumn{2}{|c|}{ U.K. } & \multicolumn{2}{|c|}{ U.S. } \\
\hline & $L^{*} / L$ & $\delta$ & $L^{*} / L$ & $\delta$ & $L^{*} / L$ & $\delta$ \\
\hline 1990 & - & - & - & - & 1.07 & 0.26 \\
\hline 1991 & - & - & 0.75 & 0.65 & 1.06 & 0.22 \\
\hline 1992 & 1.26 & 0.10 & 0.81 & 0.22 & 1.07 & 0.32 \\
\hline 1993 & 0.26 & 0.16 & 0.64 & 0.31 & 1.00 & 0.25 \\
\hline 1994 & 0.63 & 0.08 & 0.63 & 0.26 & 1.06 & 0.27 \\
\hline 1995 & 1.00 & 0.13 & 0.82 & 0.11 & 1.14 & 0.30 \\
\hline 1996 & 0.42 & 0.11 & 1.12 & 0.13 & 1.09 & 0.24 \\
\hline 1997 & 1.04 & 0.12 & - & - & - & - \\
\hline 1998 & 1.00 & 0.00 & - & - & - & - \\
\hline
\end{tabular}

Notes: Sweden: Unbalanced panel 1991-1998, 117-221 observations per year. U. K.: Balanced panel 1990-1996, 122 observations. U. S.: Balanced panel 1989-1996, 438 observations

Source: The results for U.K and for U.S is from Banjerjee, Heshmati Wihlborg (2000)

Table 6. Parameter estimates of the dynamic structure model. The elasticity of leverage defined as book value and the adjustment speed. Swedish firms

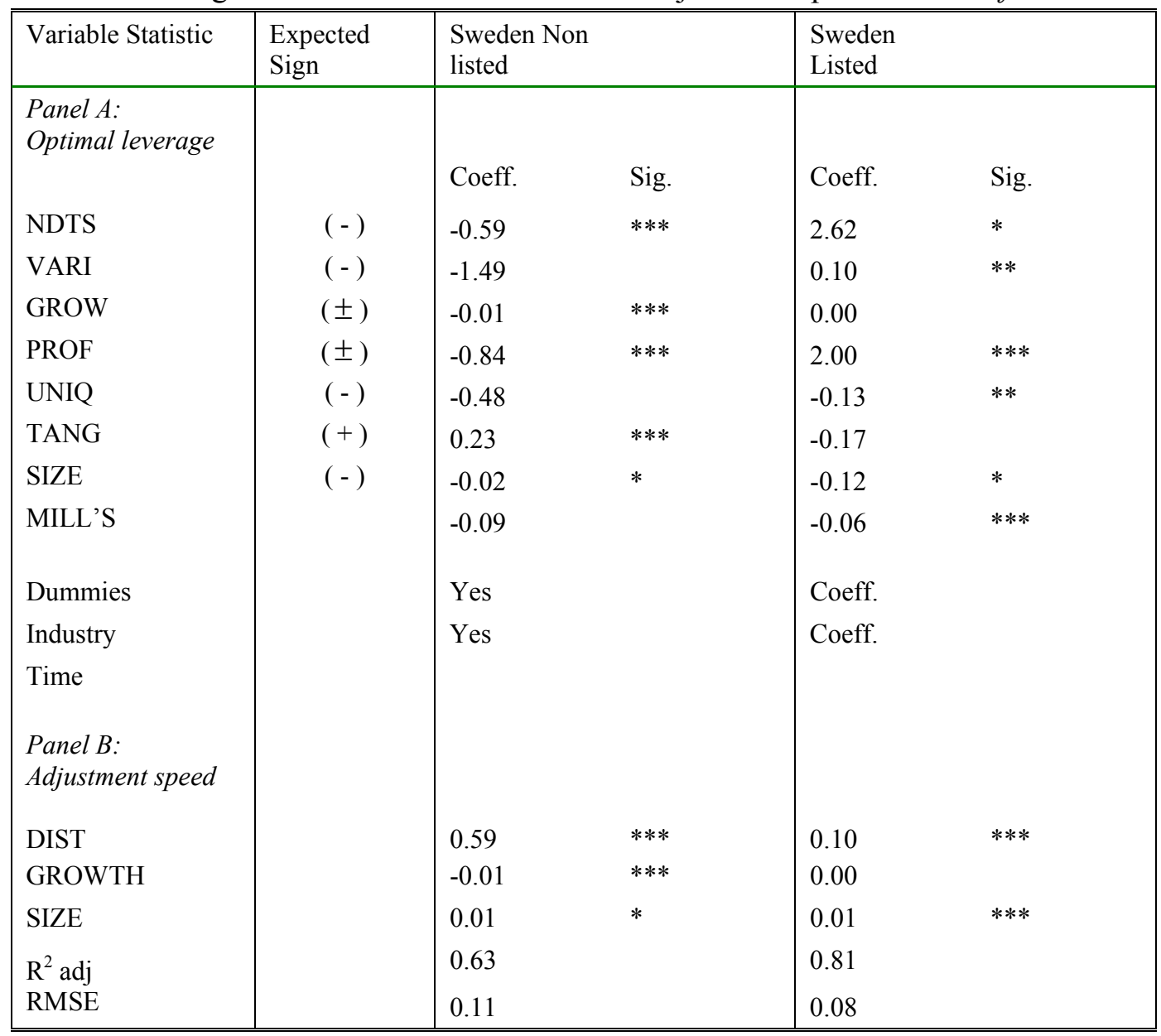

Source: The results for non listed firms are from Heshmati (2002) 